\title{
Recruitment Variability of Alewives in Lake Michigan
}

\author{
Charles P. Madenjian* \\ U.S. Geological Survey, Great Lakes Science Center, \\ 1451 Green Road, Ann Arbor, Michigan 48105, USA \\ TOMAs O. HöÖK AND Edward S. Rutherford \\ Institute for Fisheries Research, University of Michigan, \\ 212 Museums Annex, Ann Arbor, Michigan 48109, USA \\ Doran M. Mason and Thomas E. Croley II \\ National Oceanic and Atmospheric Administration, \\ Great Lakes Environmental Research Laboratory, \\ 2205 Commonwealth Boulevard, Ann Arbor, Michigan 48105, USA \\ Emily B. Szalai and James R. Bence \\ Department of Fisheries and Wildlife, Michigan State University, \\ East Lansing, Michigan 48824, USA
}

\begin{abstract}
We used a long-term series of observations on alewife Alosa pseudoharengus abundance that was based on fall bottom-trawl catches to assess the importance of various abiotic and biotic factors on alewife recruitment in Lake Michigan during 1962-2002. We first fit a basic Ricker spawner-recruit model to the lakewide biomass estimates of age-3 recruits and the corresponding spawning stock size; we then fit models for all possible combinations of the following four external variables added to the basic model: an index of salmonine predation on an alewife year-class, an index for the spring-summer water temperatures experienced by alewives during their first year in the lake, an index of the severity of the first winter experienced by alewives in the lake, and an index of lake productivity during an alewife year-class's second year in the lake. Based on an information criterion, the best model for alewife recruitment included indices of salmonine predation and spring-summer water temperatures as external variables. Our analysis corroborated the contention that a decline in alewife abundance during the 1970s and early 1980s in Lake Michigan was driven by salmonine predation. Furthermore, our findings indicated that the extraordinarily warm water temperatures during the spring and summer of 1998 probably led to a moderately high recruitment of age-3 alewives in 2001, despite abundant salmonines.
\end{abstract}

A key problem in fisheries research is predicting recruitment from a given level of spawning stock size (Sissenwine et al. 1988; Myers et al. 2001; Kehler et al. 2002). Fish recruitment can be strongly influenced by many abiotic and biotic factors, including water temperature, water movements, predation, and spawning stock size (Sissenwine 1984; Hilborn and Walters 1992). Although important factors affecting recruitment may vary across ecosystems (Madenjian et al. 1996), interesting patterns may emerge by comparing recruitment analyses for populations of a species across ecosystems (Myers 1998).

An invasion of alewives Alosa pseudoharengus during the 1940s proved to be an important stressor to the Lake Michigan ecosystem (Wells and

\footnotetext{
* Corresponding author: chuck_madenjian@usgs.gov

Received December 17, 2003; accepted August 6, 2004
}

McLain 1973). Alewives consume pelagic fry of certain native fishes, and declines in native fish abundance during the 1960s have been linked to alewives (Madenjian et al. 2002b). Additionally, the alewife invasion caused a shift in the size structure of the Lake Michigan zooplankton community (Wells 1970). To reduce alewife abundance as one of its goals, a major salmonine stocking program was launched in 1965 (Stewart et al. 1981). The salmonine stocking program appeared to effectively reduce alewife abundance during the 1970 s and early 1980s and maintain reduced alewife abundance from the early 1980s through 2000 (Madenjian et al. 2002b). Furthermore, the stocking of salmonines, especially Chinook salmon $\mathrm{On}$ corhynchus tshawytscha, created a new, valuable, and high-profile recreational fishery (Bence and Smith 1999; Hansen and Holey 2002; Tanner and Tody 2002).

Management of the salmonine fisheries is par- 
tially dependent on knowledge of alewife population dynamics (Stewart et al. 1981; Jones et al. 1993; Brown et al. 1999). The simulation model SIMPLE, developed by Jones et al. (1993), as well as the more refined simulation model developed by Szalai (2003), requires knowledge of an alewife stock-recruitment relationship to generate longterm predictions of lakewide alewife and salmon biomasses into the future. The SIMPLE simulation model has been offered as a tool for management decisions regarding the Chinook salmon fisheries in Lakes Ontario and Michigan (Brown et al. 1999; Szalai 2003).

In Lake Ontario, recruitment of age-1 alewives has been positively correlated with the warm water temperatures of May-July, during which time alewife spawning, egg incubation, hatching, and early larval development typically occur (O'Gorman et al. 2004). Apparently, relatively warm water temperatures during spring and early summer are conducive to relatively high survival of alewife eggs and larvae. In fact, the warmest May-July water temperatures during 1978-2000 occurred in 1998, the year of the strongest alewife year-class produced in Lake Ontario over this 23-year period.

O'Gorman et al. (2004) also noted that alewife recruitment to age 1 was negatively correlated with winter duration. Apparently, survival of alewives during their first winter in Lake Ontario decreased as winter duration increased. A modified Ricker spawner-recruit model, including the external variables of May-July degree-days and winter duration, explained about $70 \%$ of the variation in age1 alewife recruitment in Lake Ontario (O'Gorman et al. 2004). Additionally, O'Gorman et al. (2004) discovered a positive correlation between lake productivity and survival of alewives during their second year in Lake Ontario. O'Gorman et al. (2004) proposed that intraspecific competition for zooplankton was the likely mechanism to explain this positive correlation; the authors suggested that zooplankton abundance decreased with decreasing lake productivity. To calculate an index of salmonine predation, the authors used the product of the total number of salmonines stocked each year and the relative survival of Chinook salmon stocked in the Salmon River (New York). Although the authors concluded that salmonine predation on alewives had a significant and negative effect on survival of alewives during their second year in Lake Ontario, they acknowledged that a more accurate indicator of salmonine predation should be developed.

The O'Gorman et al. (2004) study demonstrated the importance of climatic effects on alewife recruitment in Lake Ontario, but the study also generated new questions. Would these same climatic effects be important regulators of alewife recruitment in Lake Michigan? Would the Lake Michigan data set be more amenable to demonstrating the importance of salmonine predation in determining alewife recruitment? The available data for Lake Michigan offer a unique opportunity to assess the importance of various potential factors affecting alewife recruitment. A lakewide bottom-trawl survey of prey fishes in Lake Michigan began in 1973, whereas bottom trawling at a limited number of locations was performed during 1962-1972 (Hatch et al. 1981; Krause 1999). Using age-based population models coupled with bioenergetics modeling, estimates of annual consumption of alewives by salmonines in Lake Michigan have been generated for each year since 1965 (Madenjian et al. 2002b). Long-term data series for water temperatures in Lake Michigan are available.

The objective of this study was to determine the importance of four environmental factors (predation by salmonines, spring-summer water temperatures, winter severity, and lake productivity) on alewife recruitment in Lake Michigan. This objective was accomplished by fitting a basic Ricker spawner-recruit model for Lake Michigan alewives and then adding the external variables to the Ricker spawner-recruit model to determine if explanatory power of the model could be substantially improved. We also compared our findings with those of O'Gorman et al. (2004) to better understand mechanisms regulating alewife recruitment in the Great Lakes.

\section{Methods}

Field sampling.-Since 1962, the Great Lakes Science Center (GLSC) has sampled the prey fish community in Lake Michigan each fall using bottom trawls at standard locations. During 19621966, sampling was conducted along a single transect off Saugatuck, Michigan. Sampling was expanded to four transects starting in 1967 and became lakewide in 1973 (Hatch et al. 1981; Krause 1999), at which time seven transects were sampled annually (Frankfort [Michigan], Ludington [Michigan], Saugatuck [Michigan], Waukegan [Illinois], Port Washington [Wisconsin], Sturgeon Bay [Wisconsin], and Manistique [Michigan]; Madenjian et al. 2003). Within a transect, tow depths ranged from 9 to $110 \mathrm{~m}$ in 9 -m depth increments. At each sampling depth, a bottom trawl (12-m headrope) was dragged along the depth contour for $10 \mathrm{~min}$ 
(Hatch et al. 1981). Towing speed averaged 3.4 $\mathrm{km} / \mathrm{h}$ (Fleischer et al. 2000). Fish caught in the bottom trawl were sorted by species, counted, and weighed in aggregate. When total catch was large (exceeding about $20 \mathrm{~kg}$ ), a random sample of roughly $10-15 \mathrm{~kg}$ was sorted, counted, and weighed; the remainder of the catch was then weighed and composition was estimated by direct proportion. Length frequency distribution of alewives was determined by measuring (to the nearest $\mathrm{mm}$ total length [TL]) a random sample of up to 200 alewives from each trawl haul. In this study, we used the trawl survey data as a source of recruitment and stock size estimates.

For aging, alewives were subsampled from the bottom-trawl catches at Saugatuck, Ludington, and Waukegan each year during 1967-1996. During 1973-1982, alewives at Frankfort, Port Washington, Sturgeon Bay, and Manistique were also aged. During 1983-1996, alewives at Saugatuck, Ludington, Waukegan, and Sturgeon Bay were aged (Madenjian et al. 2003). Due to time constraints in completing the survey, no age sampling of alewives was conducted at any of the transects during 1992. Due to additional time constraints imposed on the survey, aging of alewives from Saugatuck was terminated after 1996, whereas aging of alewives at Ludington, Waukegan, and Sturgeon Bay continued through 2002.

Alewives were stored on ice and processed within $24 \mathrm{~h}$ of capture. We sampled up to seven fish from each 5-mm size-class for each transect-year combination. Each alewife was measured (nearest $\mathrm{mm} \mathrm{TL}$ ) and weighed to the nearest g. Prior to 1984, scales were taken from each alewife, placed in envelopes, and transported to the GLSC. During 1984-2002, otoliths were used to age alewives; either the whole fish or the head of the fish was frozen for otolith extraction at the GLSC. Because nearly all alewives less than $100 \mathrm{~mm}$ TL from Lake Michigan during fall have been classified as age-0 fish (Norden 1967; Brown 1972; Jude et al. 1981), we did not sample any alewife less than $100 \mathrm{~mm}$ TL for aging purposes. O'Gorman et al. (1987) observed differences between alewife ages based on scales versus otoliths from Lakes Ontario, $\mathrm{Hu}-$ ron, and Michigan and found the most pronounced differences among Lake Ontario alewives and the least pronounced differences among Lake Michigan alewives. Further, the frequency of discrepancies between otolith age and scale age for Lake Michigan alewives did not exceed $13 \%$, and the average difference between otolith age and scale age did not exceed 0.15 years until alewife TL exceeded $170 \mathrm{~mm}$. Mean length at age of Lake Michigan alewives in the fall averaged $170 \mathrm{~mm}$ for age-3 fish during the 1984-1994 period (Madenjian et al. 2003). Hence, the frequency and degree of inaccuracy in age assignment due to scale aging was low for age-3-and-younger alewives in Lake Michigan.

Laboratory processing.-To use scales as aging structures, we followed the procedure outlined by Brown (1972) to determine alewife age. To use otoliths as aging structures, we followed the general procedure described by Casselman (1987) to determine alewife age. For more details, refer to Madenjian et al. (2003).

Construction of alewife biomass time series.We defined recruitment as the lakewide biomass of age-3 alewives in the fall, and we defined spawning stock size as the lakewide biomass of alewives greater than or equal to $150 \mathrm{~mm}$ TL four falls previously. We chose to study recruitment at age 3 because (1) catch of age- 0 alewives in the fall during our bottom-trawl survey was not a reliable indicator of future year-class strength (Madenjian et al. 2002a); (2) catch of age-1 alewives in the fall was lower than the catch of any other age-group between the ages of 0 and 4 (Eck and Brown 1985; Krause 1999); and (3) alewives were fully recruited to the bottom trawl by age 3 for most years during 1962-1995 (Krause 1999). Of all age-groups, the age- 3 group was the most reliable indicator of year-class strength during 19622002. Based on observations by Brown (1972), all alewives greater than or equal to $150 \mathrm{~mm}$ TL were considered spawners. We considered the estimated spawner abundance for the fall of year $i$ to be the most appropriate measure (of the available estimates) of abundance of spawning alewives in the spring and summer of year $i+1$, because the fall estimate for year $i$ included a measure of all yearclasses that would be spawning in year $i+1$ and because the growing season was nearly complete by the end of October (Madenjian et al. 2003). Spawning stock biomass is a more reliable measure of spawning stock size than number of spawners (Hilborn and Walters 1992). We considered biomass of recruits a more appropriate measure of alewife recruitment in Lake Michigan than number of recruits, because (1) alewife growth and condition have changed over time (Madenjian et al. 2003), and (2) biomass of recruits is a more reliable measure of egg production potential than number of recruits.

To maximize the contrast in spawning stock levels, we opted to include data from 1962 to 1972 
in addition to the 1973-2002 data when developing stock-recruitment relationships for Lake Michigan alewives. Hilborn and Walters (1992) identified lack of contrast in spawning stock levels as a major problem in exploring stock-recruitment relationships in fish populations. Alewives achieved unusually high levels of abundance in Lake Michigan during the mid-1960s (Brown 1972; Krause 1999). Further, inclusion of 19621972 data maximized the contrast in annual consumption of alewives by salmonines. Salmonine predation on alewives was practically negligible during 1960-1964, but salmonine predation on alewives increased rapidly between 1965 and 1980 (Madenjian et al. 2002b).

Our indices for spawning stock size and recruitment during 1973-2002 were based on "swept-area" estimates calculated with the algorithm outlined in Argyle et al. (1998) and Fleischer et al. (2000). These estimates were calculated based on data from the seven regularly sampled transects (Fleischer et al. 2000). Our spawning stock biomass index was simply the swept-area estimate for biomass of fish greater than or equal to $150 \mathrm{~mm}$ TL. Our recruitment index was calculated by first developing a swept-area estimate of age-1-and-older alewife biomass and then multiplying this by an estimate of the proportion of age-1-and-older alewife biomass represented by age-3 fish. For reasons mentioned above, biomass of alewives age- 1 and older was determined as the biomass of alewives with TL greater than or equal to $100 \mathrm{~mm}$. The proportion of age- 3 fish was determined based on age-length keys, following the procedure outlined by DeVries and Frie (1996), for each year in which sufficient age data were available.

Our indices for spawning stock size and recruitment during 1962-1972 were based on extrapolating results obtained at Saugatuck to the entire lake. We first calculated two factors (one factor for spawner biomass and a second factor for biomass of age-1-and-older fish) to convert lakewide biomass based solely on the Saugatuck transect to lakewide biomass based on the seven regularly sampled transects. A conversion factor for both age-1-and-older alewives and spawner alewives was computed by forming a ratio of the average lakewide biomass based on the seven transects over the 1973-2002 period with the average lakewide biomass based solely on the Saugatuck transect over the 1973-2002 period. The Saugatuck estimate was generated using the swept-area algorithm described above, but now applying the
Saugatuck alewife density to all portions of the lake. Next, we estimated lakewide biomass of age1-and-older alewives and spawner alewives for each year during 1962-1972 based solely on the Saugatuck transect. Finally, we multiplied these lakewide estimates for the 1962-1972 period based solely on the Saugatuck transect by the appropriate conversion factors to generate lakewide estimates of age-1-and-older biomass and spawner biomass based on the seven regularly sampled transects.

To determine whether the above-described extrapolations from Saugatuck to the entire lake were biased, we calculated the "predicted" lakewide estimates of both spawner biomass and age-1-andolder biomass for 1973-2002 by multiplying the appropriate conversion factor by the lakewide estimate based solely on the Saugatuck transect. For both the spawner biomass and the age-1-and-older biomass, simple linear regression analysis was then performed with the "predicted" lakewide estimate as a function of the "observed" lakewide estimate; the "observed" estimate refers to the estimate based on data from all seven transects. The "predicted" lakewide estimates were biased if the slope of the regression line was significantly different from one or the intercept was significantly different from zero.

No alewife aging was performed in 1962-1964, 1966, and 1992, and the aging performed during 1965 was insufficient to develop an age-length key. Therefore, age-length keys for years 19671972 were averaged, and this average age-length key was applied to the length frequency distribution for each of the years between 1962 and 1966; this same procedure was used by Krause (1999) to reconstruct abundance indices for various age-groups of alewives during 1962-1966. Similarly, we averaged age-length keys for 19891991 and 1993-1995, and this average age-length key was applied to the 1992 length frequency distribution. Problems with deployment of the trawling gear during 1998 precluded use of 1998 alewife biomass estimates in our stock-recruitment analyses (Madenjian et al. 2002a). Additionally, because only three of seven transects were sampled during 2000, alewife biomass estimates for that year were not included in our stock-recruitment analyses.

Construction of time series for external variables.-We used the annual alewife consumption estimates presented by Madenjian et al. (2002b) for 1965-1998 to derive an index of salmonine predation (PRED) on alewives. For 1962-1964, we 
assumed that annual alewife consumption by salmonines was zero, because the major salmonine stocking program in Lake Michigan did not begin until 1965 (Madenjian et al. 2002b). For 19992002, we assumed that annual alewife consumption by salmonines was equal to average annual consumption over years 1996-1998. The PRED index for year-class $i$ was set equal to the sum of the estimate of annual consumption of small ( $\leq$ $120 \mathrm{~mm}$ TL) alewives by salmonines during year $i$, the average of annual consumption of small and large ( $>120 \mathrm{~mm}$ TL) alewives by salmonines during year $i+1$, the annual consumption of large alewives during year $i+2$, and the annual consumption of large alewives during year $i+3$. Thus, the PRED index reflected the intensity of predation by salmonines experienced by an alewife yearclass during its time spent in Lake Michigan (Stewart et al. 1981; Madenjian et al. 2002b).

To construct lakewide indices for spring-summer water temperatures (SUMMER) and for winter severity (WINTER), we used a model of evaporation and thermodynamic fluxes in Lake Michigan developed by researchers at the Great Lakes Environmental Research Laboratory. The model is based on an energy balance at the lake's surface and on a one-dimensional (vertical) superposition of lake heat storage. The model generates daily vertical water temperature distributions in the lake based on daily values of air temperature, wind speed, humidity, and cloud cover at many surface locations (Croley 1989, 1992; Croley and Assel 1994). The model predictions show good agreement with actual daily Lake Michigan surface water temperatures during 1991-1995 (Croley 1989, 1992). Inputting meteorological data, the model was used to generate daily depth profiles of lakewide average water temperature in Lake Michigan from 1962 through 2002; each profile contained water temperature at depths in 1-m increments from the lake surface to the bottom (282 $m)$. For both the SUMMER index and the WINTER index, we used water temperature estimates for the upper $20 \mathrm{~m}$ of the water column since both age- 0 and age- 1 alewives occupy the epilimnion during the summer in Lake Michigan (Stewart and Binkowski 1986). To calculate the SUMMER index, we summed the degrees above $10^{\circ} \mathrm{C}$ over each combination of day and depth $(123 \mathrm{~d} \times 20$ depths $=2,460$ day-depth combinations/year) during 1 May to 31 August. If the water temperature in a day-depth combination was less than $10^{\circ} \mathrm{C}$, a value of zero was added to the sum. We used similar methodology to develop the WINTER index, which was based on data from the period of 1 December to 30 April. For each day-depth combination from this time period, we calculated the degrees below $4^{\circ} \mathrm{C}$. If the modeled temperature in a day-depth combination was greater than $4^{\circ} \mathrm{C}$, a value of zero was added to the sum. If the modeled temperature in a day-depth combination was less than $4^{\circ} \mathrm{C}$, we subtracted $4^{\circ} \mathrm{C}$ from this value. For each year, we then summed these adjusted daydepth temperatures to generate the annual WINTER index. This index is always nonpositive, with lower index scores reflecting more severe winters. Our standards of $10^{\circ} \mathrm{C}$ for summer temperature and $4^{\circ} \mathrm{C}$ for winter temperature were based on the same reasoning presented by O'Gorman et al. (2004). Our SUMMER and WINTER indices were not only more representative of lakewide water temperatures than water temperature data from a single location, but also reflected a thermal volume because the indices were based on water temperature estimates integrated over the top $20 \mathrm{~m}$ of the water column.

Construction of an index for lake productivity was problematic because a complete series of lakewide observations, including both nearshore and offshore sites, was unavailable for spring total phosphorus concentration (TP; Madenjian et al. 2002b). However, a time series of spring TP in offshore waters of Lake Michigan was available for years 1976-1998. To complete the offshore time series, we assigned spring TP for years 19621975 a value equal to the average spring TP during years 1976-1978, and we assigned spring TP for years 1999-2002 a value equal to the average based on years 1996-1998. These extrapolations were reasonable because the major reduction in phosphorus loadings to Lake Michigan did not likely occur until after 1976, and no further significant reductions in phosphorus loadings were expected after 1995 (Johengen et al. 1994; Madenjian et al. 2002b). Estimates of average spring TP in nearshore waters of Lake Michigan were available for the mid-1970s and for the 1998-2000 time period (Madenjian et al. 2002b). To construct the nearshore TP time series, we assigned spring TP for years 1962-1975 a value equal to the average spring TP value observed during the mid1970 s, then we linearly interpolated values of spring TP from 1975 to 1999, and then we assigned spring TP for years 1999-2002 a value equal to the average spring TP observed during 1998-2000. Again, these extrapolations were reasonable based on the above-cited studies. Then, for each year during 1962-2002, we averaged nearshore and off- 
shore estimates to generate an estimate of lakewide spring TP.

Spawner-recruit analyses.-Our base model was a standard Ricker spawner-recruit model, namely,

$$
R=\alpha P e^{-\beta_{P} P},
$$

where $R=$ lakewide biomass of age- 3 recruits (in kilotons [kt]; $1 \mathrm{kt}=1,000$ metric tons); $P=$ lakewide spawner biomass (kt); $\alpha=$ slope at origin (measured perhaps as $\mathrm{kg}$ of recruits $/ \mathrm{kg}$ of spawners); and $\beta_{P}=$ parameter with dimensions of $1 / P$ (Ricker 1975; Myers et al. 1999). To incorporate the multiplicative effects of external variables, we used the following form:

$$
R=\alpha P \exp \left(-\beta_{P} P+\sum_{i} \beta_{i} X_{i}\right)
$$

where $X_{i}=$ external variable $i, \beta_{i}=$ parameter with dimensions $1 / X_{i}$, and $i$ ranged from 1 to the number of external variables included in the model. The Ricker model was chosen because visual inspection of the plot of $R$ as a function of $P$ suggested some degree of density-dependent negative feedback on alewife recruitment and because the Ricker model was also chosen by O'Gorman et al. (2004) to study alewife recruitment in Lake Ontario. Error about the Ricker curve appeared to be lognormally distributed. Therefore, all model fitting was done via linear regression; both sides of equation (2) were divided by $P$, and then both sides of the resulting equation were lognormally transformed. Because we, as well as fishery managers, were interested in model performance in the arithmetic scale, we back-transformed predictions of recruitment from the logarithm scale to the arithmetic scale using the procedure outlined by Ricker (1975). We then calculated both error sum of squares and the proportion of variation in recruitment explained by the model in the arithmetic scale.

We employed the same procedure used by O'Gorman et al. (2004) to select the "best" model for the alewife spawner-recruit relationship. We fitted regression models (of the form depicted in equation 2) to the data presented in Table 1, considering all possible combinations of the four external variables. Thus, including the basic Ricker spawner-recruit model, 16 models were fitted. Akaike's information criterion (AIC), an index that balances goodness of fit with model complexity (Akaike 1969; Burnham and Anderson 2002), was calculated for each model fitted, and we selected the model with the lowest AIC as the best model. Note the AIC was corrected for small sample size (Burnham and Anderson 2002). An additional reason for using the Ricker model was that the AIC from the basic Ricker model fit was lower than that from the basic Beverton-Holt (Beverton and Holt 1957) model or basic Shepherd (1982) model fits. Finally, we determined whether the residuals from the best model fit were significantly autocorrelated by inspecting the autocorrelation function as done by Walters (1987) and Hilborn and Walters (1992).

\section{Results}

The extrapolations of biomass from Saugatuck to the entire lake for the years 1973-2002 were unbiased. The conversion factor used to make these extrapolations was estimated at 3.90 for age1 -and-older biomass and at 4.37 for spawner biomass. "Predicted" age-1-and-older biomass, using the data from only Saugatuck and then applying the appropriate conversion factor, was unbiased (slope of regression line $\pm 95 \%$ confidence interval $[\mathrm{CI}]=0.985 \pm 0.487$; intercept of regression line $\pm 95 \%$ CI $=0.592 \pm 23.909 \mathrm{kt}$ ). Similarly, "predicted" spawner biomass, using the data from only Saugatuck and then applying the appropriate conversion factor, was unbiased (slope of regression line $\pm 95 \% \mathrm{CI}=1.062 \pm 0.402$; intercept of regression line $\pm 95 \% \mathrm{CI}=-2.052 \pm 17.172 \mathrm{kt}$ ).

According to the lakewide estimates based on bottom trawling, the biomass of spawner-size alewives in Lake Michigan peaked at $311 \mathrm{kt}$ in 1966 (Figure 1; Table 1). Spawner biomass declined from 1966 to 1968, showed a modest recovery during 1969-1972, and then decreased dramatically between 1972 and 1982. Spawner biomass has remained relatively low from the early 1980 s to the present. Spawner biomass was estimated to be less than $10 \mathrm{kt}$ in 1984 and 1989 (Figure 1; Table 1). Thus, the contrast in spawner biomass over the 1962-2002 time series was more than 30fold. Estimated lakewide biomass of age-3 alewives in Lake Michigan showed a temporal pattern similar to that of alewife spawner abundance (Figure 1). Age-3 recruitment exhibited a moderate spike in 2001, which corresponded to the 1998 year-class. In fact, age-3 biomass was higher in 2001 than in any other year during 1974-2002.

The basic Ricker model applied to the data in Table 1 yielded the following fit:

$$
R=0.46 P e^{-0.0031 P,}
$$


TABLE 1.-Lakewide biomass estimate of age-3 alewives for a given year-class paired with the corresponding lakewide biomass estimate of the parental stock (alewives with total length $\geq 150 \mathrm{~mm}$ ) for year-classes 1963 through 1998 in Lake Michigan. Estimates are based on area-swept calculations applied to catches from the lakewide bottom-trawl survey performed by the Great Lakes Science Center (GLSC) during the fall. Also shown are the corresponding values for the salmonine predation index (PRED), spring-summer water temperature index (SUMMER), and winter severity index (WINTER) and estimates of the mean concentration of total phosphorus in the spring (TP). See Methods for more details.

\begin{tabular}{|c|c|c|c|c|c|c|}
\hline $\begin{array}{l}\text { Year- } \\
\text { class }\end{array}$ & $\begin{array}{l}\text { Biomass of } \\
\text { age-3 recruits } \\
(\mathrm{kt})\end{array}$ & $\begin{array}{l}\text { Biomass of } \\
\text { spawners } \\
\text { (kt) }\end{array}$ & $\begin{array}{l}\text { PRED } \\
(\mathrm{kt})\end{array}$ & $\begin{array}{c}\text { SUMMER } \\
\text { (depth degree } \\
\text { days) }\end{array}$ & $\begin{array}{c}\text { WINTER } \\
\text { (depth degree } \\
\text { days) }\end{array}$ & $\begin{array}{c}\mathrm{TP} \\
(\mu \mathrm{g} / \mathrm{L})\end{array}$ \\
\hline 1963 & 135.6 & 119.9 & 0.6 & 777 & $-9,255$ & 8.51 \\
\hline 1964 & 99.2 & 66.9 & 2.9 & 2,589 & $-9,287$ & 8.51 \\
\hline 1965 & 30.3 & 131.1 & 6.9 & 518 & $-8,998$ & 8.51 \\
\hline 1966 & 36.1 & 310.2 & 15.0 & 2,903 & $-9,281$ & 8.51 \\
\hline 1967 & 26.5 & 311.3 & 28.4 & 1,123 & $-9,817$ & 8.51 \\
\hline 1968 & 32.7 & 190.2 & 39.9 & 1,350 & $-9,602$ & 8.51 \\
\hline 1969 & 72.4 & 69.2 & 50.7 & 1,351 & $-9,934$ & 8.51 \\
\hline 1970 & 45.5 & 109.5 & 66.9 & 723 & $-9,732$ & 8.51 \\
\hline 1971 & 20.6 & 139.2 & 82.5 & 853 & $-8,862$ & 8.51 \\
\hline 1972 & 21.1 & 107.4 & 94.4 & 566 & $-9,567$ & 8.51 \\
\hline 1973 & 16.5 & 176.8 & 108.1 & 2,068 & $-8,554$ & 8.51 \\
\hline 1974 & 13.0 & 124.8 & 125.9 & 2,378 & $-7,920$ & 8.51 \\
\hline 1975 & 24.9 & 63.2 & 136.8 & 3,193 & $-7,651$ & 9.11 \\
\hline 1976 & 20.2 & 85.9 & 133.0 & 5,554 & $-10,207$ & 7.37 \\
\hline 1977 & 8.3 & 42.1 & 129.7 & 514 & $-10,098$ & 8.67 \\
\hline 1978 & 13.1 & 33.8 & 133.6 & 295 & $-10,118$ & 8.74 \\
\hline 1979 & 9.9 & 62.8 & 141.0 & 0 & $-9,685$ & 8.25 \\
\hline 1980 & 4.1 & 73.7 & 130.5 & 768 & $-10,042$ & 7.76 \\
\hline 1981 & 1.2 & 27.1 & 125.5 & 1,256 & $-9,478$ & 7.64 \\
\hline 1982 & 1.8 & 51.4 & 123.9 & 16 & $-7,816$ & 7.52 \\
\hline 1983 & 11.0 & 27.3 & 125.1 & 3,911 & $-9,762$ & 6.97 \\
\hline 1984 & 7.5 & 11.5 & 124.5 & 851 & $-9,149$ & 6.74 \\
\hline 1985 & 6.1 & 9.8 & 127.6 & 2,051 & $-9,896$ & 7.67 \\
\hline 1986 & 4.4 & 11.3 & 129.2 & 1,392 & $-6,738$ & 6.66 \\
\hline 1987 & 4.5 & 21.7 & 137.9 & 6,567 & $-7,705$ & 8.68 \\
\hline 1988 & 4.4 & 15.2 & 139.9 & 6,180 & $-7,938$ & 7.30 \\
\hline 1989 & 6.1 & 17.6 & 148.2 & 2,383 & $-9,081$ & 6.83 \\
\hline 1990 & 6.4 & 8.3 & 148.3 & 2,414 & $-7,761$ & 7.00 \\
\hline 1991 & 3.4 & 19.7 & 141.5 & 4,460 & $-6,838$ & 8.10 \\
\hline 1992 & 0.6 & 13.2 & 147.4 & 3,314 & $-8,033$ & 5.17 \\
\hline 1993 & 4.2 & 20.3 & 170.8 & 1,904 & $-9,181$ & 5.03 \\
\hline 1994 & 4.8 & 15.7 & 175.9 & 1,157 & $-6,695$ & 4.90 \\
\hline 1996 & 1.8 & 21.5 & 193.3 & 169 & $-9,648$ & 5.92 \\
\hline 1998 & 32.4 & 31.7 & 187.8 & 8,182 & $-4,885$ & 6.15 \\
\hline
\end{tabular}

which explained $18 \%$ of the variation in age- 3 recruitment. The AIC value for this model fit was 345.68 (Table 2). Highest observed recruitment coincided with spawner biomass in the 60-120-kt range (Figure 2). Observed recruitment at spawner biomass greater than $160 \mathrm{kt}$ was considerably lower than the strongest year-classes produced from spawner biomass in the 60-120-kt range, suggesting density-dependent effects on recruitment.

The best model for the alewife spawner-recruit relationship included the PRED index and the SUMMER index as external variables, that is,

$$
\begin{gathered}
R=2.18 P \exp \left(-0.0091 P-0.01406 X_{1}\right. \\
\left.+0.00015 X_{2}\right),
\end{gathered}
$$

where $X_{1}=$ PRED and $X_{2}=$ SUMMER (Table 2).
This model explained $75 \%$ of the variation in age3 recruitment and the AIC value for this model fit was 310.62. Alewife spawner stock size, salmonine predation, and spring-summer water temperatures during the alewife's first year of life in the lake had significant effects on alewife recruitment, as all three regression coefficients appearing in the exponent were significantly different from zero $\left(\beta_{P}: t=-3.66, \mathrm{df}=1, P=0.0010 ; \beta_{1}: t=-3.76\right.$, df $=1, P=0.0007 ; \beta_{2}: t=2.05$, df $=1, P=$ 0.0492). Salmonine predation had the most influence on alewife recruitment of the four external variables examined. The PRED index appeared in all eight of the eight top-ranked models (Table 2). Further, error sum of squares for the models not including the PRED index was roughly three times 

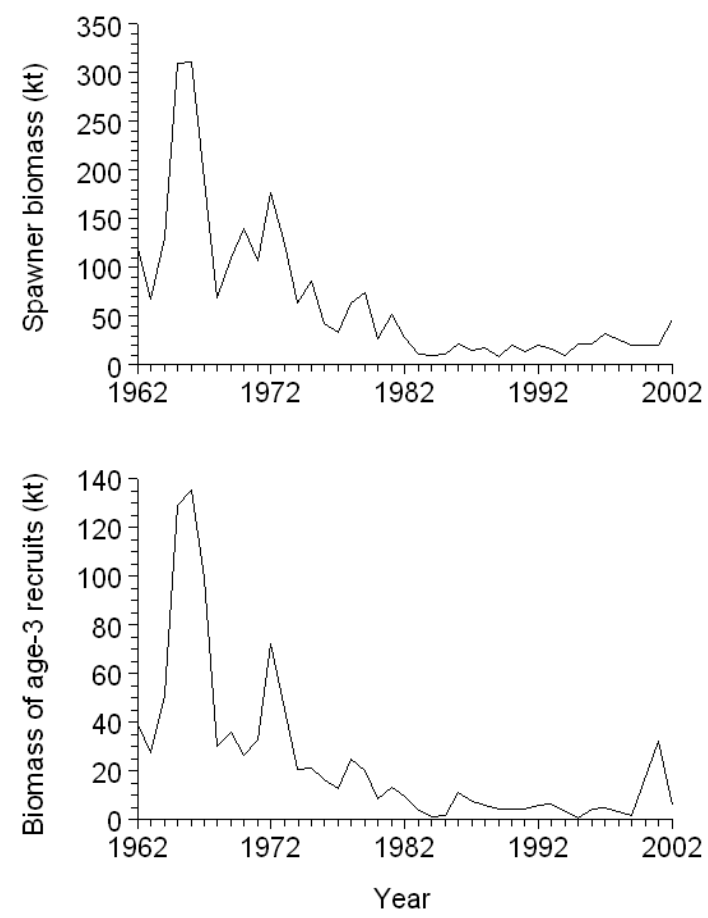

FIGURE 1.-Annual lakewide biomass estimates of spawner-size ( $\geq 150 \mathrm{~mm}$ total length; upper panel) and age-3 alewives (lower panel) during the fall in Lake Michigan, 1962-2002. Estimates were based on areaswept calculations applied to catches from the lakewide bottom-trawl survey performed by the Great Lakes Science Center; $1 \mathrm{kt}=1,000$ metric tons.

higher than the error sum of squares for models including the PRED index as an external variable. Alewife recruitment decreased substantially as the PRED index increased from 0 to $150 \mathrm{kt}$ (Figure 3 ). In contrast, alewife recruitment was positively related to spring-summer water temperature during the alewife's first year, as evidenced by the positive values for the regression coefficient corresponding with the SUMMER index (Table 2; equation 4). Residuals from the best model fit were not significantly autocorrelated (first 10 autocorrelation coefficients were not significantly different from zero; $P>0.05$ ).

The best model predictions tracked observed age-3 recruitment reasonably well (Figure 4). The greatest disparity between predicted and observed recruitment was for the 1965 year-class; the model predicted a recruitment of $84 \mathrm{kt}$, whereas observed recruitment was $30 \mathrm{kt}$. Degree of underestimation was relatively large for the 1963, 1969, and 1998 year-classes; observed recruitment for these three year-classes was 136,72 , and 32 , whereas pre- dicted recruitment values were 97,48 , and $12 \mathrm{kt}$ (Figure 4). In contrast, predicted recruitment was within $1 \mathrm{kt}$ of observed recruitment for the 1979, 1986, 1989, 1993, and 1996 year-classes.

\section{Discussion}

Comparison of our results with the findings of O'Gorman et al. (2004) revealed that salmonine predation and spring-summer water temperatures during the alewife's first year of life were important factors regulating alewife recruitment in both Lake Michigan and Lake Ontario. We found that alewife recruitment to age 3 in Lake Michigan was strongly affected by salmonine predation on alewives. Similarly, O'Gorman et al. (2004) concluded that salmonine predation had a significantly negative effect on survival of alewives from age 1 to age 2. Because the SUMMER index was included in our best model for alewife recruitment and because age- 3 alewife recruitment was moderately high in 2001 (Figure 1), despite a high degree of salmonine predation on the 1998 yearclass of alewives (Table 1), we conclude that spring-summer water temperatures during the first year of life in Lake Michigan also influenced alewife year-class strength. The highest value for our SUMMER index over the entire 1962-2002 period was for 1998 (Table 1). Coincidentally, O'Gorman et al. (2004) reported that the highest spring-summer water temperatures in Lake Ontario over the 1978-2000 period occurred in 1998. Furthermore, the strongest year-class in Lake Ontario during the 1978-2000 period, as measured by abundance of age-1 alewives in the spring, was the 1998 yearclass, and these researchers attributed this extraordinary year-class strength primarily to unusually warm water temperatures during the spring and summer of the alewife's first year of life in the lake. Apparently, warm water temperatures during the critical periods of alewife spawning and larval growth enhanced alewife recruitment in Lake Ontario because Lake Ontario was at the northern limit of the alewife's freshwater range (O'Gorman et al. 2004). Our findings pointed out that high spring-summer water temperatures during the first year of life enhanced alewife recruitment in Lake Michigan as well.

Our analyses indicated that winter severity during the first year of life in the lake did not have a major effect on alewife recruitment in Lake Michigan. In contrast, O'Gorman et al. (2004) concluded that winter duration was an important factor governing alewife recruitment in Lake Ontario. This difference in results between lakes was fur- 
TABLE 2.-Results from fitting stock-recruit regression models (see equation 2 in the text) of lakewide biomass estimates of age- 3 recruits to lakewide biomass estimates of the parental stock of Lake Michigan alewives and various external variables for year-classes 1963 through 1998. The external variables were as follows: PRED = salmonine predation index; SUMMER = spring-summer water temperature index; WINTER $=$ winter severity index; and TP = mean concentration of total phosphorus in the spring. Lakewide biomass estimates were based on area-swept calculations applied to catches from the lakewide bottom-trawl survey performed by the Great Lakes Science Center during the fall. Fitted models were ranked by Akaike's information criterion (AIC). The values of the regression coefficients for the external variables appear in same order as in the list of external variables.

\begin{tabular}{|c|c|c|c|c|c|c|c|c|c|}
\hline \multirow{2}{*}{$\begin{array}{c}\text { Model } \\
\text { rank }\end{array}$} & \multirow[b]{2}{*}{ List of external variables } & \multicolumn{6}{|c|}{ Values of regression coefficients } & \multirow{2}{*}{$\begin{array}{l}\text { Error } \\
\text { sum of } \\
\text { squares }\end{array}$} & \multirow[b]{2}{*}{ AIC } \\
\hline & & $\alpha$ & $\beta_{P}$ & $\beta_{1}$ & $\beta_{2}$ & $\beta_{3}$ & $\beta_{4}$ & & \\
\hline 1 & PRED, SUMMER & 2.18 & 0.0091 & -0.01406 & 0.00015 & & & 7,044 & 310.62 \\
\hline 2 & PRED & 2.56 & 0.0090 & -0.01239 & & & & 8,190 & 313.16 \\
\hline 3 & PRED, SUMMER, TP & 2.30 & 0.0091 & -0.01411 & 0.00015 & -0.00491 & & 7,144 & 313.86 \\
\hline 4 & PRED, SUMMER, WINTER & 3.55 & 0.0091 & -0.01433 & 0.00014 & 0.00005 & & 7,319 & 314.68 \\
\hline 5 & PRED, TP & 2.58 & 0.0090 & -0.01239 & 0.00023 & & & 8,294 & 316.17 \\
\hline 6 & PRED, SUMMER, WINTER, TP & 3.46 & 0.0091 & -0.01428 & 0.00013 & 0.00005 & 0.00523 & 7,419 & 318.11 \\
\hline 7 & PRED, WINTER & 11.50 & 0.0090 & -0.01376 & 0.00015 & & & 9,189 & 319.66 \\
\hline 8 & PRED, WINTER, TP & 9.16 & 0.0091 & -0.01344 & 0.00016 & 0.03176 & & 9,212 & 322.50 \\
\hline 9 & $\mathrm{TP}$ & 0.11 & 0.0046 & 0.20199 & & & & 21,208 & 345.51 \\
\hline 10 & & 0.46 & 0.0031 & & & & & 22,881 & 345.68 \\
\hline 11 & WINTER & 0.60 & 0.0030 & 0.00003 & & & & 23,181 & 348.54 \\
\hline 12 & SUMMER, TP & 0.08 & 0.0043 & 0.00010 & 0.21711 & & & 21,724 & 348.91 \\
\hline 13 & WINTER, TP & 0.18 & 0.0045 & 0.00008 & 0.22610 & & & 21,825 & 349.07 \\
\hline 14 & SUMMER & 0.37 & 0.0027 & 0.00009 & & & & 23,804 & 349.44 \\
\hline 15 & SUMMER, WINTER, TP & 0.07 & 0.0043 & 0.00010 & -0.00001 & 0.21545 & & 21,781 & 351.76 \\
\hline 16 & SUMMER, WINTER & 0.22 & 0.0029 & 0.00011 & -0.00006 & & & 23,786 & 351.99 \\
\hline
\end{tabular}

ther supported by previous studies. Since the start of Lake Ontario prey fish surveys (conducted by the New York Department of Environmental Conservation and the GLSC) in 1976, an overwinter survival of age-0 alewives equal to zero was documented for only one winter: the winter of 19761977 (O'Gorman and Schneider 1986; O'Gorman et al., 2004). By comparison, survival of age-0 alewives during the 1976-1977 winter in Lake Michigan was not equal to zero; rather, this sur-

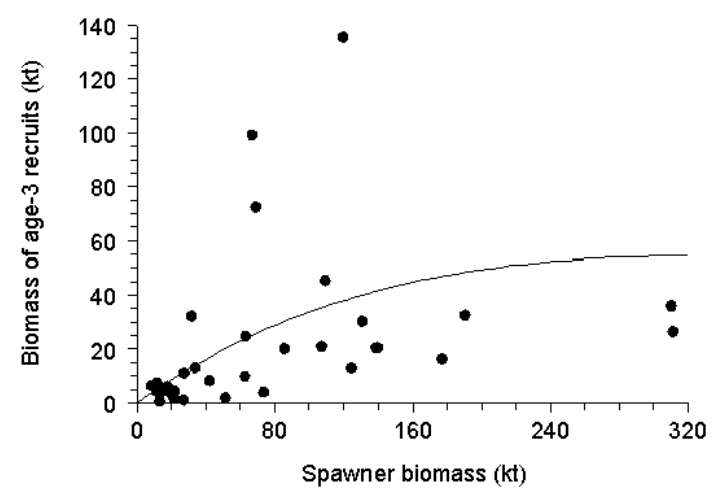

FIGURE 2.-Biomass of age-3 alewives recruited to the Lake Michigan population (as estimated from the Great Lakes Science Center bottom-trawl survey) as a function of spawner biomass (as estimated from the same survey). Data are for 1962-2002 $(N=34) ; 1 \mathrm{kt}=1,000$ metric tons. Also shown is the fitted Ricker curve. vival was approximately equal to an average value for Lake Michigan age-0 alewives during the 1970s (Krause 1999). According to our analyses, the 1976 year-class was one of the strongest yearclasses produced in Lake Michigan during the 1970s (Figure 4). If winter duration or winter severity had to exceed some threshold level before

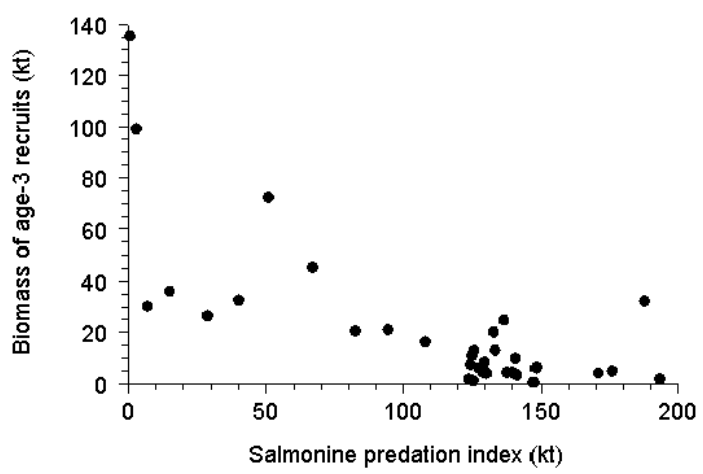

FIGURE 3.-Biomass of age-3 alewives recruited to the Lake Michigan population (as estimated from the Great Lakes Science Center bottom-trawl survey) as a function of the salmonine predation index. The salmonine predation index reflected the degree of predation by salmonines experienced by an alewife year-class and was based on bioenergetics modeling applied to the salmonine population in Lake Michigan. See Methods for more details. Data are for 1962-2002 $(N=34) ; 1 \mathrm{kt}=1,000$ metric tons. 


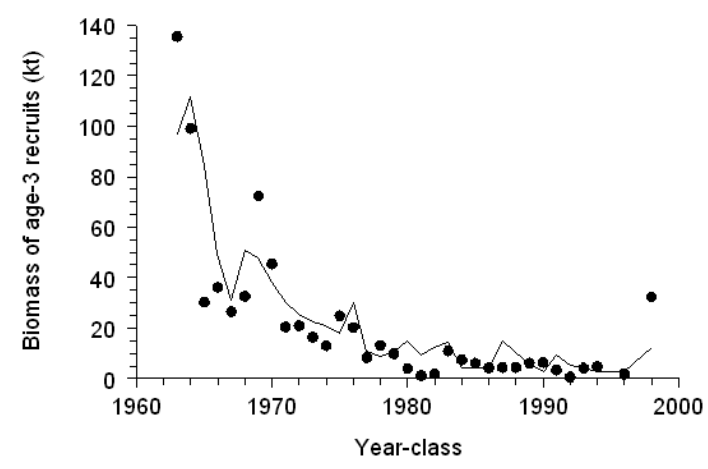

FIgURE 4.-Actual (circles) and predicted biomass (solid line) of age-3 alewives recruited to the Lake Michigan population for year-classes 1963 through 1998. Actual biomass was estimated from the Great Lakes Science Center bottom-trawl survey, whereas predictions were based on the regression model represented by equation (4) in the text.

alewife overwinter survival was seriously affected, and if winter duration or winter severity was greater in Lake Ontario than in Lake Michigan, then this difference between lakes would be reconcilable. Another plausible explanation would be that age- 0 alewives in Lake Michigan were in better condition to survive the winter than age- 0 alewives in Lake Ontario.

Our analyses also suggested that lake productivity during the second year of life in the lake has not yet had an important effect on alewife recruitment in Lake Michigan. In contrast, O'Gorman et al. (2004) proposed that lake productivity was an important regulator of alewife survival from age 1 to age 2 in Lake Ontario during 1978-2000. Perhaps this difference could be explained by the difference in the magnitude of the lakes' responses to the reduction in phosphorus loadings. Reduction in phosphorus loadings to Lake Ontario during the 1970 s and 1980s resulted in more than a $60 \%$ decrease in spring TP (averaging across both nearshore and offshore waters) during 1970-1990 (Mills et al. 2003). Conversely, the response of Lake Michigan to phosphorus loadings was not nearly as dramatic. Spring TP decreased about $40 \%$ in the nearshore zone between the mid-1970s and 1998-2000, whereas spring TP in the offshore waters did not appreciably decrease during 19702000 (Madenjian et al. 2002b). Furthermore, alewife density has been substantially greater in Lake Ontario than in Lake Michigan (Madenjian et al. 2003) and, therefore, competition for zooplankton between age- 1 and adult alewives may have been much more drastic in Lake Ontario than in Lake Michigan.

The paucity of information on nearshore TP represented the greatest information gap in our analysis of alewife recruitment in Lake Michigan. Nevertheless, the conclusion that TP has not yet been an important factor regulating alewife recruitment in Lake Michigan was not surprising. Alewife recruitment declined substantially during the 1970s (Figure 1), yet the most significant decrease in phosphorus loading to the lake occurred between 1980 and 1981 (Johengen et al. 1994; Madenjian et al. 2002b). Thus, large temporal changes in alewife recruitment were not associated with relatively large changes in lake productivity. In contrast, phosphorus loading to Lake Ontario decreased substantially during the 1970 s and, consequently, both mean summer chlorophyll- $a$ concentration and total epilimnetic zooplankton production declined during the 1980s (Mills et al. 2003). O'Gorman et al. (2004) partly attributed the declining trend in Lake Ontario alewife survival from age 1 to age 2 during 1978-2000 to decreasing lake productivity.

Corroborating evidence from the commercial fishery indicated that our extrapolations from the Saugatuck transect to the entire lake in order to estimate lakewide biomass of alewife spawners and age-3 recruits for years 1962-1972 were justified. Based on these extrapolations, the maximum biomass of spawner-size alewives in Lake Michigan occurred in 1966 (Figure 1). In support of our extrapolations, maximum catch per unit effort of alewives from commercial trawls also occurred in 1966 (Brown 1972; Baldwin et al. 1979).

Although our approach of adding external variables to a Ricker spawner-recruit model allowed us to compare our results with those of O'Gorman et al. (2004) for Lake Ontario, our approach precluded us from directly contrasting carrying capacity per unit area between lakes. In applying meta-analysis to populations of Atlantic cod Gadus morhua, Myers et al. (2001) fitted Beverton-Holt stock-recruitment functions to each of the populations. They determined that carrying capacity per unit area varied more than 20 -fold among populations. Hayes et al. (1996) showed that use of a Beverton-Holt stock-recruitment function facilitated the assessment of the effect of a $25 \%$ increase in the amount of suitable spawning substrate on lake whitefish Coregonus clupeaformis recruitment.

Our findings corroborated the contention that the reduction in alewife abundance in Lake Mich- 
igan during the 1970 s was driven by salmonine predation. Madenjian et al. (2002b) reported a significantly negative correlation between annual estimates of alewife biomass (all age-groups pooled) and annual estimates of salmonine consumption during 1973-1999, and they concluded that salmonine predation was likely responsible for the marked decrease in alewife abundance during the 1970s and early 1980s. In the present study, we considered an array of environmental variables that could potentially affect recruitment of alewives to age 3 in Lake Michigan. According to our analyses, most of the variation in age- 3 recruitment between 1962 and 2002 was explained by salmonine predation. By examining the entire time series between 1962 and 2002, we not only maximized the contrast in salmonine predation on alewives, but we also maximized the contrast in alewife spawner biomass. As mentioned earlier, the biomass of spawner-size alewives peaked in 1966. Prior to 1965 , salmonine predation on alewives was negligible; however, annual consumption of alewives by salmonines in Lake Michigan exceeded $60 \mathrm{kt}$ by 1980 and approached $100 \mathrm{kt}$ in 1996 and 1998 (Madenjian et al. 2002b). Hilborn and Walters (1992) warned that the most serious problem in most stock-recruitment data sets is lack of contrast in spawning stock levels. Analogously, we reasoned that contrast in an environmental variable should be maximized to accurately evaluate the factor's effect on recruitment. Therefore, our analysis of the 1962-2002 data set was especially appropriate for assessing the importance of salmonine predation on alewife recruitment.

Comparison of maximum reproductive rates (defined as the lifetime recruitment of new stock produced by a unit of stock at low population sizes) for Lake Michigan alewives with the maximum reproductive rate for anadromous alewives from the Atlantic coast indicated that predation has an important effect on maximum reproductive rate. We followed up our recruitment analysis for Lake Michigan alewives by calculating maximum reproductive rate of Lake Michigan alewives using equation (4) and mortality schedules associated with no salmonine predators and 1996-1998 levels of salmonine predators taken from Szalai (2003). In these calculations, we assumed all fish matured at age 2, we used weight-at-age schedules based on no-predator data from 1984 to 1991 and 1996 to 1998 as well as $1996-1998$ predator-level conditions (Madenjian et al. 2003), and we used an average SUMMER index. Without predators, the maximum reproductive rate for Lake Michigan alewives was 18.56 , which greatly exceeds the value of 6 reported for marine anadromous alewife populations (Myers et al. 1999), whereas the maximum reproductive rate for the 1996-1998 predator levels in Lake Michigan was 0.70, far below that reported for the anadromous stocks. These results suggest that alewives in Lake Michigan are presently subjected to substantially higher levels of predation than the anadromous stocks, which also suffer mortality during spawning migrations. With a maximum reproductive rate under 1.0, alewives in Lake Michigan may not be able to sustain their population under average temperatures and recent levels of predation.

Our study has furnished valuable results for both fish ecologists and fishery managers. As recommended by Myers (1998), we have compared our recruitment analysis for Lake Michigan with O'Gorman et al.'s (2004) recruitment analysis for Lake Ontario alewives to look for consistency of findings across ecosystems. The comparison revealed that both salmonine predation on alewives and spring-summer water temperature during the first year of life were important factors regulating alewife recruitment in both ecosystems. Myers (1998) surmised that for fish populations near the northern limit of their range, recruitment appeared to be positively linked with water temperatures; this statement was based on examination of data for several species of fish, including Atlantic cod and Pacific herring Clupea harengus. Thus, our study has shown that the recruitment dynamics of alewife populations behave similarly to the recruitment dynamics of these other fish populations. Our results have also shown that salmonine predation does exert a controlling influence on alewife recruitment in the Great Lakes. The results of our study should prove useful in developing and refining decision models for salmon stocking in the Great Lakes, as these models require knowledge of the alewife stock-recruitment relationship. Finally, gaining these insights into alewife recruitment dynamics would not have been possible without the availability of long-term observations on alewife abundance and age structure of the population, and we agree with Myers (1998) that fishery-independent surveys, such as our Lake Michigan prey fish survey, are most useful for studying fish recruitment.

\section{Acknowledgments}

We thank E. Brown, T. Desorcie, G. Eck, C. Hatcher, J. Holuszko, S. Jorgenson, R. Stedman, and L. Wells for making major contributions to- 
ward the completion of the long-term surveys of Lake Michigan prey fish, as well as toward the analysis and maintenance of the resulting database, during 1962-2002. J. Holuszko and S. Nelson developed the age-length keys. R. Claramunt, J. Dettmers, R. Myers, and J. Savino provided helpful reviews of the manuscript. This work was funded, in part, by The Great Lakes Fishery Trust through Grant Award No. 2000.11. This article is Contribution 1295 of the U.S. Geological Survey Great Lakes Science Center.

\section{References}

Akaike, H. 1969. Fitting autoregressive models for prediction. Annals of the Institute of Statistical Mathematics 21:243-247.

Argyle, R. L., G. W. Fleischer, G. L. Curtis, J. V. Adams, and R. G. Stickel. 1998. An integrated acoustic and trawl-based strategy for Lake Michigan: a report to the Illinois Department of Natural Resources, Indiana Department of Natural Resources, Michigan Department of Natural Resources, and Wisconsin Department of Natural Resources. U.S. Geological Survey, Great Lakes Science Center, Ann Arbor, Michigan.

Baldwin, N. S., R. W. Saalfeld, M. A. Ross, and H. J. Buettner. 1979. Commercial fish production in the Great Lakes, 1867-1977. Great Lakes Fishery Commission, Technical Report 3, Ann Arbor, Michigan.

Bence, J. R., and K. D. Smith. 1999. An overview of recreational fisheries of the Great Lakes. Pages 259-306 in W. W. Taylor and C. P. Ferreri, editors. Great Lakes fisheries and policy management: a binational perspective. Michigan State University Press, East Lansing.

Beverton, R. J. H., and S. J. Holt. 1957. On the dynamics of exploited fish populations. Fisheries Investigations Series II. Marine Fisheries, Great Britain Ministry of Agriculture, Fisheries and Food 19.

Brown, E. H., Jr. 1972. Population biology of alewives, Alosa pseudoharengus, in Lake Michigan, 1949-70. Journal of the Fisheries Research Board of Canada 29:477-500.

Brown, E. H., Jr., T. R. Busiahn, M. L. Jones, and R. L. Argyle. 1999. Allocating Great Lakes forage bases in response to multiple demand. Pages 355-394 in W. W. Taylor and C. P. Ferreri, editors. Great Lakes fisheries and policy management: a binational perspective. Michigan State University Press, East Lansing.

Burnham, K. P., and D. R. Anderson. 2002. Model selection and multimodel inference: a practical information-theoretic approach, 2nd edition. Springer, New York.

Casselman, J. M. 1987. Determination of age and growth. Pages 209-242 in A. H. Weatherley and H. S. Gill, editors. The biology of fish growth. Academic Press, New York.

Croley, T. E., II. 1989. Verifiable evaporation modeling on the Laurentian Great Lakes. Water Resources Research 25:781-792.

Croley, T. E., II. 1992. Long-term heat storage in the Great Lakes. Water Resources Research 28:69-81.

Croley, T. E., II, and R. A. Assel. 1994. One-dimensional ice model for the Laurentian Great Lakes. Water Resources Research 30:625-639.

DeVries, D. R., and R. V. Frie. 1996. Determination of age and growth. Pages 483-512 in B. R. Murphy and D. W. Willis, editors. Fisheries techniques, 2nd edition. American Fisheries Society, Bethesda, Maryland.

Eck, G. W., and E. H. Brown, Jr. 1985. Lake Michigan's capacity to support lake trout (Salvelinus namaycush) and other salmonines: an estimate based on the status of prey populations in the 1970s. Canadian Journal of Fisheries and Aquatic Sciences 42: 449-454.

Fleischer, G. W., C. P. Madenjian, T. J. DeSorcie, and J. D. Holuszko. 2000. Status and trends of prey fish populations in Lake Michigan, 1999. Great Lakes Fishery Commission, Ann Arbor, Michigan.

Hansen, M. J., and M. E. Holey. 2002. Ecological factors affecting the sustainability of Chinook and coho salmon populations in the Great Lakes, especially Lake Michigan. Pages 155-180 in K. D. Lynch, M. L. Jones, and W. W. Taylor, editors. Sustaining North American salmon: perspectives across regions and disciplines. American Fisheries Society, Bethesda, Maryland.

Hatch, R. W., P. M. Haack, and E. H. Brown, Jr. 1981. Estimation of alewife biomass in Lake Michigan, 1967-1978. Transactions of the American Fisheries Society 110:575-584.

Hayes, D. B., C. P. Ferreri, and W. W. Taylor. 1996. Linking fish habitat to their population dynamics. Canadian Journal of Fisheries and Aquatic Sciences 53(Supplement 1):383-390.

Hilborn, R., and C. J. Walters. 1992. Quantitative fisheries stock assessment: choice, dynamics, and uncertainty. Chapman and Hall, New York.

Johengen, T. H., O. E. Johannsson, G. L. Pernie, and E. S. Millard. 1994. Temporal and seasonal trends in nutrient dynamics and biomass measures in Lakes Michigan and Ontario in response to phosphorus control. Canadian Journal of Fisheries and Aquatic Sciences 51:2570-2578.

Jones, M. L., J. F. Koonce, and R. O'Gorman. 1993. Sustainability of hatchery-dependent salmonine fisheries in Lake Ontario: the conflict between predator demand and prey supply. Transactions of the American Fisheries Society 122:1002-1018.

Jude, D. J., H. T. Tin, G. R. Heufelder, P. J. Schneeberger, C. P. Madenjian, T. L. Rutecki, P. J. Mansfield, N. A. Auer, and G. E. Noguchi. 1981. Adult, juvenile, and larval fish populations in the vicinity of the $\mathrm{J}$. H. Campbell Power Plant, eastern Lake Michigan, 1977-1980. University of Michigan, Great Lakes Research Division Special Report 86, Ann Arbor.

Kehler, D. G., R. A. Myers, and C. A. Field. 2002. Measurement error and bias in the maximum reproduc- 
tive rate for the Ricker model. Canadian Journal of Fisheries and Aquatic Sciences 59:854-864.

Krause, A. E. 1999. Sampling variability of ten fish species and population dynamics of alewife (Alosa pseudoharengus) and bloater (Coregonus hoyi) in Lake Michigan. Master's thesis. Michigan State University, East Lansing.

Madenjian, C. P., T. J. DeSorcie, and J. D. Holuszko. 2002a. Status and trends of prey fish populations in Lake Michigan, 2001. Great Lakes Fishery Commission, Ann Arbor, Michigan.

Madenjian, C. P., G. L. Fahnenstiel, T. H. Johengen, T. F. Nalepa, H. A. Vanderploeg, G. W. Fleischer, P. J. Schneeberger, D. M. Benjamin, E. B. Smith, J. R. Bence, E. S. Rutherford, D. S. Lavis, D. M. Robertson, D. J. Jude, and M. P. Ebener. 2002b. Dynamics of the Lake Michigan food web, 1970-2000. Canadian Journal of Fisheries and Aquatic Sciences 59:736-753.

Madenjian, C. P., J. D. Holuszko, and T. J. Desorcie. 2003. Growth and condition of alewives in Lake Michigan, 1984-2001. Transactions of the American Fisheries Society 132:1104-1116.

Madenjian, C. P., J. T. Tyson, R. L. Knight, M. W. Kershner, and M. J. Hansen. 1996. First-year growth, recruitment, and maturity of walleyes in western Lake Erie. Transactions of the American Fisheries Society 125:821-830.

Mills, E. L., J. M. Casselman, R. Dermott, J. D. Fitzsimons, G. Gal, K. T. Holeck, J. A. Hoyle, O. E. Johannsson, B. F. Lantry, J. C. Makarewicz, E. S. Millard, I. F. Munawar, M. Munawar, R. O'Gorman, R. W. Owens, L. G. Rudstam, T. Schaner, and T. J. Stewart. 2003. Lake Ontario: food web dynamics in a changing ecosystem (1970-2000). Canadian Journal of Fisheries and Aquatic Sciences 60:471490.

Myers, R. A. 1998. When do environment-recruitment correlations work? Reviews in Fish Biology and Fisheries 8:285-305.

Myers, R. A., K. G. Bowen, and N. J. Barrowman. 1999. Maximum reproductive rate of fish at low population sizes. Canadian Journal of Fisheries and Aquatic Sciences 56:2404-2419.

Myers, R. A., B. R. MacKenzie, K. G. Bowen, and N. J. Barrowman. 2001. What is the carrying capacity for fish in the ocean? A meta-analysis of population dynamics of North Atlantic cod. Canadian Journal of Fisheries and Aquatic Sciences 58:1464-1476.

Norden, C. R. 1967. Age, growth, and fecundity of the alewife Alosa pseudoharengus (Wilson) in Lake Michigan. Transactions of the American Fisheries Society 96:387-393.

O'Gorman, R., D. H. Barwick, and C. A. Bowen. 1987. Discrepancies between ages determined from scales and otoliths for alewives from the Great Lakes. Pages 203-210 in R. C. Summerfelt and G. E. Hall, editors. Age and growth of fish. Iowa State University Press, Ames.

O'Gorman, R., B. F. Lantry, and C. P. Schneider. 2004. Effect of stock size, climate, predation, and trophic status on recruitment of alewives in Lake Ontario, 1978-2000. Transactions of the American Fisheries Society 133:855-867.

O'Gorman, R., and C. P. Schneider. 1986. Dynamics of alewives in Lake Ontario following a mass mortality. Transactions of the American Fisheries Society 115:1-14.

Ricker, W. E. 1975. Computation and interpretation of biological statistics of fish populations. Fisheries Research Board of Canada Bulletin 191.

Shepherd, J. G. 1982. A versatile new stock-recruitment relationship for fisheries and the construction of sustainable yield curves. Journal du Conseil, Conseil International pour 1'Exploration de la Mer 40:6775 .

Sissenwine, M. P. 1984. Why do fish populations vary? Pages 59-64 in R. M. May, editor. Exploitation of marine communities. Springer-Verlag, Berlin.

Sissenwine, M. P., M. J. Fogarty, and W. J. Overholtz. 1988. Some fisheries management implications of recruitment variability. Pages $129-152$ in J. A. Gulland, editor. Fish population dynamics. Wiley, Chichester, UK.

Stewart, D. J., and F. P. Binkowski. 1986. Dynamics of consumption and food conversion by Lake Michigan alewives: an energetics modeling synthesis. Transactions of the American Fisheries Society 115 : 643-661.

Stewart, D. J., J. F. Kitchell, and L. B. Crowder. 1981. Forage fishes and their salmonid predators in Lake Michigan. Transactions of the American Fisheries Society 110:751-763.

Szalai, E. B. 2003. Dynamics of bloater growth and the predator-prey dynamics between alewife and Chinook salmon in Lake Michigan. Doctoral dissertation. Michigan State University, East Lansing.

Tanner, H. A., and W. H. Tody. 2002. History of the Great Lakes salmon fishery: a Michigan perspective. Pages 139-154 in K. D. Lynch, M. L. Jones, and W. W. Taylor, editors. Sustaining North American salmon: perspectives across regions and disciplines. American Fisheries Society, Bethesda, Maryland.

Walters, C. J. 1987. Nonstationarity of the production relationships in exploited populations. Canadian Journal of Fisheries and Aquatic Sciences 44(Supplement 2):156-165.

Wells, L. 1970. Effects of alewife predation on zooplankton populations in Lake Michigan. Limnology and Oceanography 15:556-565.

Wells, L., and A. McLain. 1973. Lake Michigan: man's effects on native fish stocks and other biota. Great Lakes Fishery Commission, Technical Report 20, Ann Arbor, Michigan. 